\title{
Response of Central Plains Tallgrass Prairies to fire, fertilizer, and atrazine
}

\author{
ROBERT A. MASTERS, KENNETH P. VOGEL, AND ROBERT B. MITCHELL
}

\author{
Authors are range scientist and supervisory research geneticist, USDA-ARS, and research assistant, Department of \\ Agronomy, University of Nebraska, Lincoln 68583.
}

\begin{abstract}
Tallgrass prairies are an important forage resource in the eastern Central Great Plains. The effect of spring burning, fertilization, and atrazine [6-chloro-N-ethyl-N'-(1-methylethyl)-1,3,5-triaxine2,4-diamine] on standing crop of selected herbaceous species and categories of vegetation was determined in 6 tallgrass prairie environments located near Lincoln and Virginia, Neb., from 1987 through 1989 and 1 site near Bloomfield, Neb., in 1987. The grasslands were in good to excellent condition at the time these studies were conducted. Portions of each site were burned in mid-to late spring, atrazine was applied at a rate of $2.2 \mathrm{~kg} \mathrm{a.i.} \mathrm{ha}^{-1}$ in late April to early May, and fertilizer was applied in mid-May. Despite below-normal precipitation at 6 of the 7 sites, burning combined with fertilization improved warm-season grass standing crop by 50 to $127 \%$ in 5 of the 7 grassland environments studied. This reflected the positive response of the dominant warm-season grasses, big bluestem (Andropogon gerardit Vitman var. gerardii Vitman) and indiangrass [Sorghastrum nutans (L.) Nash], to burning or fertilization. Atrazine increased warm-season grass standing crop at only the site near Bloomfield. Kentucky bluegrass (Poa pratensis L.) and annual bromes (Bromus spp.) were more susceptible to atrazine than smooth brome (Bromus inermis Leyss.). Forb standing crop was significantly reduced by atrazine alone or by burning followed by atrazine application in 4 of the 7 prairie environments. Burning combined with fertilizer application improved warm-season grass standing crop in good to excellent condition grasslands and obviated the need to use atrazine.
\end{abstract}

Key Words: herbaceous standing crop, big bluestem (Andropogon gerardii Vitman var. gerardii Vitman), indiangrass [Sorghastrum nutans (L.) Nash], smooth brome (Bromus inermis Leyss.), Kentucky bluegrass (Poa pratensis L.), warm-season grasses, coolseason grasses, forbs

Tallgrass prairies occur throughout the eastern Central Great Plains of North America and are a valuable resource that can provide high quality warm-season grass forage if properly managed. In this region abundant cool-season forages and crop residues are available for grazing by livestock in the spring, fall, and winter (Waller and Schmidt 1983). However, there is an imbalance in seasonal forage supply because of a lack of warmseason grass forage during the summer. Because of this imbalance, there is a tendency for producers to overstock their warm-season forages, which often leads to deterioration of this resource.

\footnotetext{
The authors wish to thank Mark Dragastin, Kevin Grams, Jim Kube, Terry Gompert, and G. Allen Rasmussen for assistance in completion of this project. Support provided by Steven Waller in 1989 is appreciated. We appreciate the Animal Science Department, University of Nebraska-Lincoln and Nine-Mile Prairie Committee for allowing us to conduct these studies at the Dalbey-Halleck Farm and Nine-Mile Prairie, respectively. This paper reports the results of research only. Mention of a pesticide in this paper does not constitute a recommendation by the USDA or the University of Nebraska nor does it imply registration under FIFRA.

Contribution Number 9577 of the Agricultural Research Division, University of Nebraska, Lincoln, and the USDA-ARS.

Manuscript accepted 22 August 1991.
}

Increasing the productivity of the warm-season forages found on existing tallgrass prairies that are in good to excellent condition could improve availability of forage in the summer.

Methods to improve productivity of tallgrass prairies include spring burning, fertilization, and application of atrazine [6-chloroN-ethyl-N'-(1-methylethyl)-1,3,5-triazine-2,4-diamine]. Factors that influence the response of tallgrass-dominated plant communities to these treatments include vegetation composition and successional status (Gillen et al. 1987), time of spring burning (Towne and Owensby 1984), and time of fertilizer application (Rehm 1984). Atrazine has been applied to selectively control introduced coolseason grasses Kentucky bluegrass (Poa pratensis L.) and smooth brome (Bromus inermis Leyss.) and improve productivity of warm-season grasses in degraded tallgrass prairies (Samson and Moser 1982, Waller and Schmidt 1983).

A management strategy that combines atrazine application with fertilization and burning in the spring could improve productivity of warm-season grasses in eastern Central Great Plains tallgrass prairies and alleviate limitations in summer forage supply. The importance of atrazine as a component of a management program must be assessed and other strategies identified because of the suspension of this herbicide from use on rangeland. A series of studies were conducted in tallgrass prairies in good to excellent condition to determine the influence of these treatments on standing crop of the warm- and cool-season grass and forb components of these plant communities and to determine if there is any advantage to including atrazine in a treatment regime with burning and fertilization to improve tallgrass prairie productivity.

\section{Materials and Methods}

Three studies were conducted during a 3 year period from 1987 through 1989 in 7 environments to determine the response of tallgrass-dominated plant communities to burning, fertilization, and atrazine application in the spring. Plant community response to treatments was assessed and livestock were excluded from the study sites the year of treatment.

\section{Study 1}

In 1987, sites were established on grasslands located $15 \mathrm{~km}$ northwest of Lincoln, Neb., (Nine-Mile Prairie) and $10 \mathrm{~km}$ southwest of Bloomfield, Neb. The soil at the site near Lincoln was a Sharpsburg silty clay loam (Typic Arguidoll) and near Bloomfield was a Dickinson loamy sand (Typic Hapludoll). The Lincoln site was a tallgrass prairie that had not been grazed and had been burned at 2 to 3 year intervals since 1968. The Bloomfield site supported a grassland community that had been grazed annually since revegetation with tall- and mid-grasses in the 1950's.

One-half of an area (148 $\times 54-\mathrm{m})$ was burned at the Lincoln and Bloomfield sites on 18 April and 23 April 1987, respectively. Three plots $(74 \times 18-\mathrm{m})$ were delineated within the burned and unburned areas at each site. In May 1987, one-half of each plot was fertilized with $110 \mathrm{~kg} \mathrm{~N} \mathrm{ha}^{-1}$. In addition, $22 \mathrm{~kg} \mathrm{P} \mathrm{ha}^{-1}$ was applied at the Bloomfield site because the soil was phosphorus deficient. Atra- 
Table 1. Botanical composition of tallgrass prairies near Bloomfield, Lincoln, and Virginia, Nebraska.'

\begin{tabular}{|c|c|c|c|c|c|c|c|}
\hline & \multicolumn{2}{|c|}{1987} & \multicolumn{3}{|c|}{1988} & \multicolumn{2}{|c|}{1989} \\
\hline & Bloomfield & Lincoln & Lincoln & Virginia-G & Virginia-H & Lincoln & Virginia \\
\hline Big bluestem & $\cdots$ & 68 & 78 & $=-\%=-$ & $\cdots$ & -7 & -1 \\
\hline Indiangrass & 40 & $\begin{array}{l}68 \\
13\end{array}$ & $\begin{array}{r}78 \\
2\end{array}$ & $\begin{array}{l}19 \\
28\end{array}$ & $\begin{array}{l}11 \\
29\end{array}$ & $\begin{array}{l}60 \\
16\end{array}$ & $\begin{array}{l}42 \\
14\end{array}$ \\
\hline Prairie/Tall dropseed & 0 & 0 & 0 & 41 & 12 & 1 & 11 \\
\hline Other warm-season grasses & 48 & 12 & 7 & 2 & 36 & 4 & 6 \\
\hline Smooth brome & 7 & 0 & 0 & 0 & 4 & 0 & 7 \\
\hline Kentucky bluegrass & $\mathbf{N H}^{2}$ & NH & 9 & 1 & 1 & 1 & 9 \\
\hline $\begin{array}{l}\text { Scribner's/Wilcox's } \\
\text { panicum }\end{array}$ & 3 & 1 & 0 & 4 & 3 & 1 & 6 \\
\hline $\begin{array}{l}\text { Other cool-season } \\
\text { grasses }\end{array}$ & 0 & 1 & 0 & $\mathbf{0}$ & $\mathbf{0}$ & 1 & 0 \\
\hline Sedge & 1 & 3 & 0 & 2 & 2 & 5 & 4 \\
\hline Forbs & 1 & 2 & 4 & 3 & 2 & 10 & 1 \\
\hline
\end{tabular}

1Expressed as a percent of total herbaceous standing crop.

2Not harvested separately (NH).

zine was applied at $2.2 \mathrm{~kg}$ active ingredient (a.i.) ha ${ }^{-1}$ to half of each fertilized and unfertilized plot within the burned and unburned areas. In early August 1987 , vegetation within two $0.5-\mathrm{m}^{2}$ quadrats placed within each subplot was clipped to a $2-\mathrm{cm}$ stubble height, separated by species, oven-dried, and weighed.

\section{Study 2}

In 1988 sites were established on tallgrass prairies near Lincoln (Nine-Mile Prairie) and Virginia (Dalbey-Halleck Farm), Neb. The soil at the site near Lincoln was a Sharpsburg silty clay loam and that near Virginia was a Pawnee clay loam (Aquic Argiudoll). The Lincoln site had a similar history to the tallgrass prairie in Study 1. Two sites located $5 \mathrm{~km}$ south of Virginia on a tallgrass prairie were used in this study. For a period of 25 years before initiation of this study, 1 site (Virginia-G) had been moderately grazed for 50 to 60 days during the summer and the other site (Virgina-H) had been hayed in late July or early August. The Virginia-G site was sprayed with atrazine at $4.4 \mathrm{~kg} \mathrm{a.i.} \mathrm{ha}{ }^{-1}$ in 1986 and with 1.1 or $2.2 \mathrm{~kg}$ a.i. $\mathrm{ha}^{-1}$ of $2,4-\mathrm{D}$ [(2,4-dichloro-phenoxy)acetic acid] each year from 1982 to 1987 . Both sites were burned in mid-April 1986 and 1987.

Eight plots $(10 \times 20-\mathrm{m})$ were established at each site in April 1988. Four of these plots were burned on 6 May 1988. After burning four, $5 \times 10-\mathrm{m}$ subplots were delineated within each main plot. On 12 May 1988 randomly selected subplots were fertilized at a rate of $110-22 \mathrm{~kg} \mathrm{~N}-\mathrm{P} \mathrm{ha}{ }^{-1}$ and atrazine was applied at a rate of 2.2 kg a.i. ha $^{-1}$ to 1 fertilized and 1 unfertilized subplot within each plot. In August 1988, vegetation within $2,0.25 \mathrm{~m}^{2}$ quadrats randomly placed within each subplot was clipped to a $2-\mathrm{cm}$ stubble height, separated by species, oven-dried, and weighed.

\section{Study 3}

In 1989 study sites were established on tallgrass prairies near Lincoln (Nine-Mile Prairie) and Virginia (Dalbey-Halleck Farm), Neb. The soil at the site near Lincoln was a Shelby clay loam (Typic Argiudoll) and that near Virginia was a Pawnee clay loam. Management of the Lincoln and Virginia sites was similar to that in Study 1 and Virginia-G in Study 2, respectively, except that the site near Lincoln was burned by a wildfire on 10 March 1988.

Eight plots $(10 \times 20-\mathrm{m})$ were delineated at each site in April 1989. Four plots were burned on 19 April and 20 April 1989 at Virginia and Lincoln, respectively. After burning, four, $5 \times 10-\mathrm{m}$ subplots were delineated within each main plot. On 26 April 1989 atrazine was applied at a rate of $2.2 \mathrm{~kg} \mathrm{a.i.} \mathrm{ha}{ }^{-1}$ to 2 randomly selected subplots within each main plot. In mid-May fertilizer at a rate of $67-22 \mathrm{~kg} \mathrm{~N}^{-} \mathrm{P} \mathrm{ha}^{-1}$ was applied within each burn treatment main

Table 2. Mean standing crop and F-test probabilities of warm-season grasses harvested in the summer after applications of fire, fertilizer, and atraxine in the spring to grassland sites near Bloomfield, Lincoln, and Virginia, Nebraska.

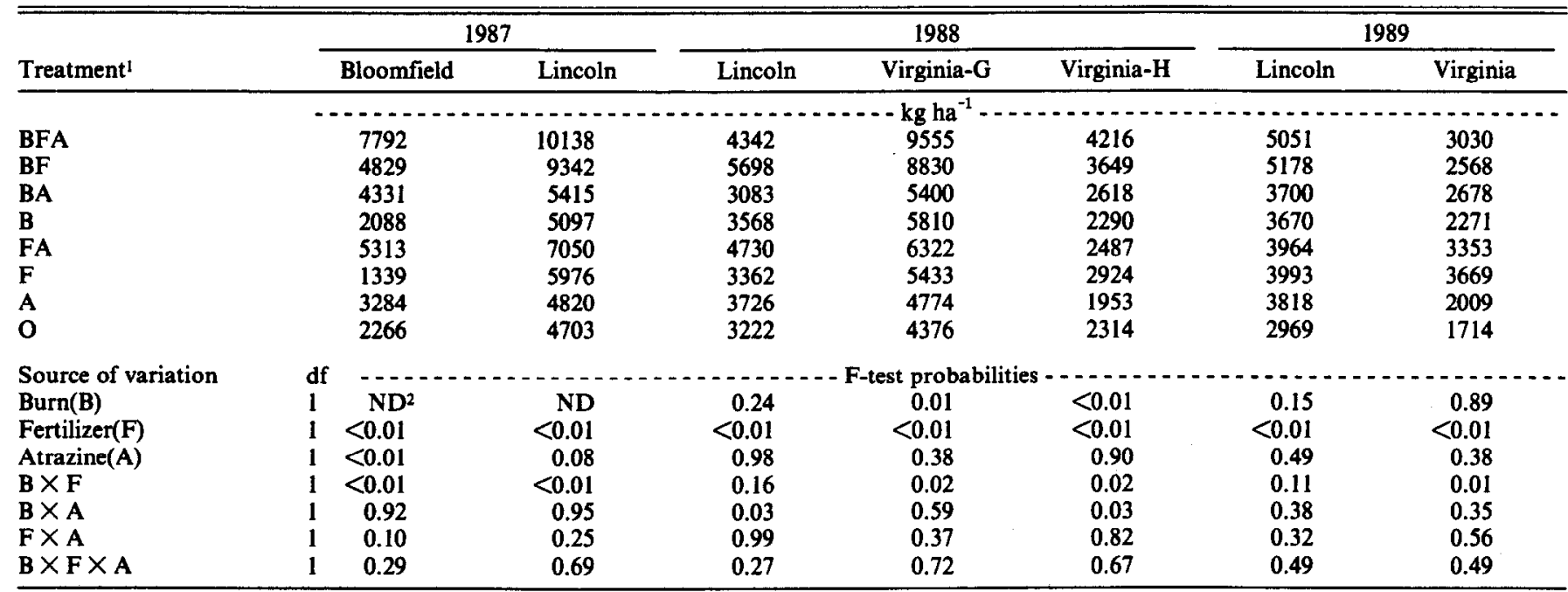

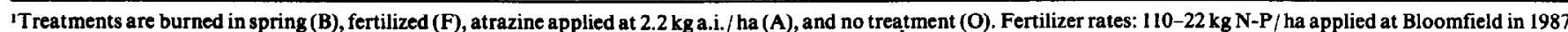
and Lincoln and Virginia in $1988,110 \mathrm{~kg} \mathrm{~N} / \mathrm{ha}$ applied at Lincoln in 1987, and $67-22 \mathrm{~kg} N-P / \mathrm{ha}^{-1}$ applied at Lincoln and Virginia in 1989.

${ }^{2}$ Main effect of burning could not be determined because the whole plots were non-replicated. 
plot to 1 subplot that had been treated with atrazine and 1 that had not. In late July 1989 , vegetation within two $0.25-\mathrm{m}^{2}$ quadrats randomly placed within each subplot was clipped to a 2-cm stubble height, separated by species, oven dried, and weighed.

\section{Botanical Composition}

The sites used in these studies were in good to excellent condition as indicated by botanical composition (Table 1). The grassland near Bloomfield was dominated by indiangrass [Sorghastrum nutans (L.) Nash] and little bluestem [Schizachyrium scoparium (Michx.) Nash], with each comprising $40 \%$ of the warm-season grasses, while big bluestem (Andropogon gerardii Vitman var. gerardii Vitman) was uncommon. At the sites near Lincoln, big bluestem constituted $60 \%$ or more of the herbage with indiangrass as the next most common species except on the site treated in 1988. Indiangrass, tall dropseed [Sporobolus asper (Michx.) Kunth], prairie dropseed [Sporobolus heterolepis (Gray) Gray], and big bluestem were the most common grasses at the tallgrass prairie sites near Virginia. The cool-season grass component of the 7 grassland environments evaluated in these studies ranged from 1 to $10 \%$ except at the site near Virginia in 1989 which contained $22 \%$ cool-season grasses. The most common cool-season grasses were smooth brome, Kentucky bluegrass, Scribner's panicum [ Dicanthelium oligosanthes (Schult.) Gould var. scribnerianum Nash], and Wilcox's panicum [Dicanthelium oligosanthes (Schult.) Gould var. wilcoxianum (Vasey) Gould and Clark].

\section{Experiment Design and Data Analyses}

Study 1 was designed as a randomized complete block arranged as a split-split plot. Burning treatments constituted the whole plots, but were not replicated. Fertilizer and atrazine treatments were the subplots and sub-subplots, respectively, and were replicated 3 times within the burned and unburned whole plots. Because whole plots were nonreplicated, an error term could not be generated to test the main effect of burning. Despite the restriction in placement of burn treatments, appropriate error terms could be developed to test fertilizer and atrazine main effects and interactions with each other and burning (Anderson and McLean 1974). Testing the interactions that include burning are appropriate if the differences observed in plant response resulted from burning and not other factors unique to the burned or unburned whole plots. Given the similarity in botanical composition, soil characteristics, and management history between the whole plots at each site, we were confident that interactions with burning could be tested. Data from burned and unburned whole plots at each site were pooled after the error variances were determined to be equal. Equality of error variances was determined using a F-test where $P \leq 0.05$ (Steel and Torrie 1980). Studies 2 and 3 were designed as randomized complete blocks arranged as split plots with 4 replications per
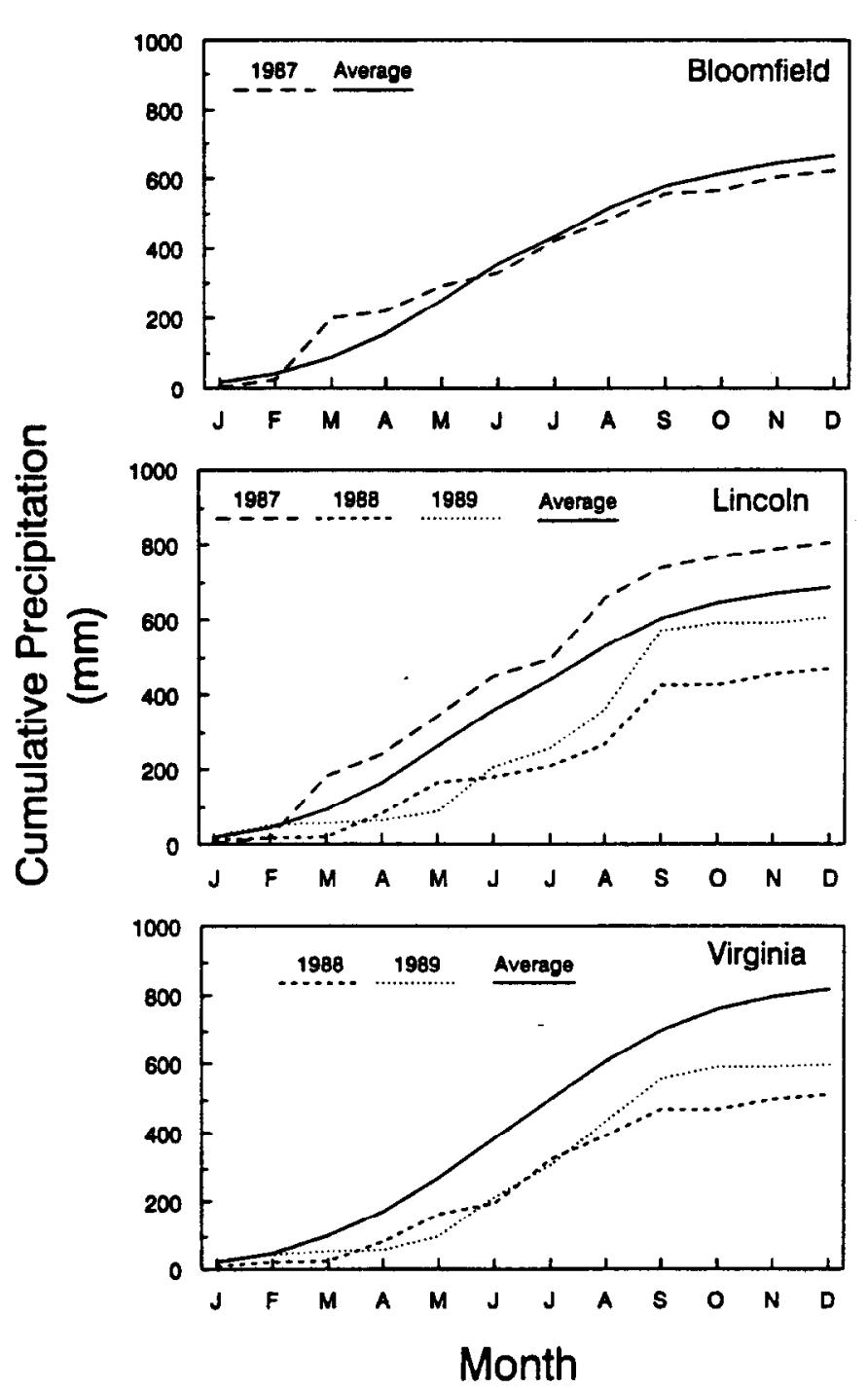

Fig. 1. Cumulative precipitation at 3 locations in eastern Nebraska during the time that these studies were conducted.

treatment combination. Burning treatments were the whole plots and fertilizer and atrazine treatments were randomly assigned subplots within the replicated whole plots. Hierarchial analysis of variance was used in each study to determine the influence of main effects (except main effect of burning 1987) and interactions on

Table 3. Mean standing crop of warm-season grasses harvested in the summer, following applications of fire, fertilizer, and atrazine in the spring to tallgrass prairies near Bloomfield, Lincoln, and Virginia, Nebraska1.

\begin{tabular}{|c|c|c|c|c|c|c|c|c|}
\hline \multirow{2}{*}{$\begin{array}{l}\text { Spring } \\
\text { burning }\end{array}$} & \multirow[b]{2}{*}{ Fertilizer $^{2}$} & \multicolumn{2}{|c|}{1987} & \multicolumn{3}{|c|}{1988} & \multicolumn{2}{|c|}{1989} \\
\hline & & Bloomfield & Lincoln & Lincoln & Virginia-G & Virginia-H & Lincoln & Virginia \\
\hline $\begin{array}{l}\text { None } \\
\text { None } \\
\text { Burn } \\
\text { Burn } \\
\quad \text { LSD }(0.05)\end{array}$ & $\begin{array}{l}\text { None } \\
\text { Fertilize } \\
\text { None } \\
\text { Fertilize }\end{array}$ & $\begin{array}{r}2775 \\
3326 \\
3210 \\
6311 \\
934\end{array}$ & $\begin{array}{l}4761 \\
6513 \\
5246 \\
9741 \\
1303\end{array}$ & $\begin{array}{l}3474 \\
4046 \\
3325 \\
5020 \\
\text { NS }^{3}\end{array}$ & $\begin{array}{r}-\mathrm{kg} \mathrm{ha}^{-1}- \\
4595 \\
5877 \\
5605 \\
9192 \\
1325\end{array}$ & $\begin{array}{c}2133 \\
2705 \\
2454 \\
3932 \\
535\end{array}$ & $\begin{array}{c}3394 \\
3978 \\
3685 \\
5115 \\
\text { NS }\end{array}$ & $\begin{array}{r}1861 \\
3511 \\
2474 \\
2799 \\
694\end{array}$ \\
\hline
\end{tabular}

IStanding crop averaged across atrazine treatments.

${ }_{2}^{2}$ Fertilizer rates: $110-22 \mathrm{~kg} \mathrm{~N}-\mathrm{P} / \mathrm{ha}^{-1}$ applied at Bloomfield in 1987 and Lincoln and Virginia in $1988,110 \mathrm{~kg} \mathrm{~N} / \mathrm{ha}^{-1}$ applied at Lincoln in 1987 , and $67-22 \mathrm{~kg} \mathrm{~N}-\mathrm{P} / \mathrm{ha}{ }^{-1}$ applied at Lincoln and Virginia in 1989.

${ }^{3}$ Not significant at $P \leq 0.05$ level of probability. 
Table 4. Mean standing crop of warm-season (Warm) and cool-season (Cool) grasses harvested in the summer following applications of fire, fertilizer, and atraxine in the spring to tallgrass prairies near Bloomfield, Lincoln, and Virginia, Nebraska.

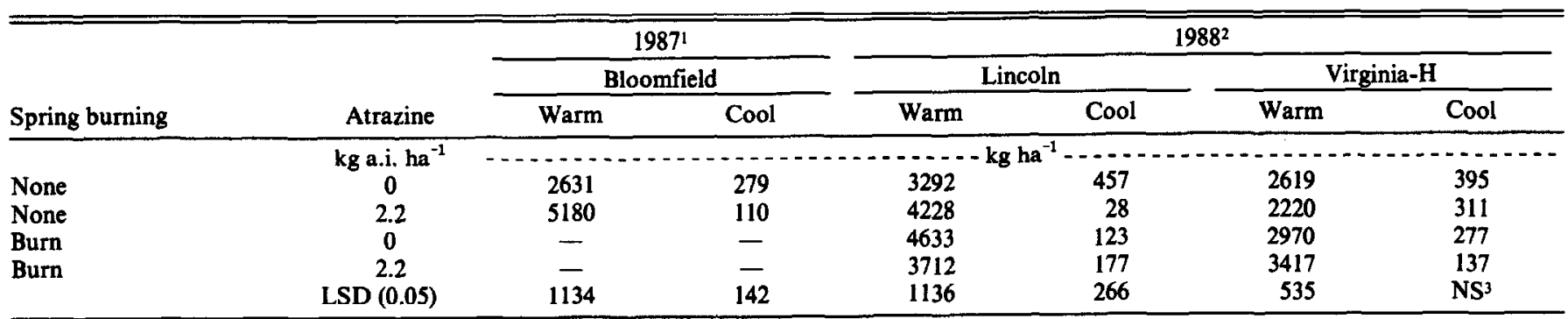

'Standing crop averaged over burning and fertilizer treatments.

2Standing crop averaged over fertilizer treatments.

${ }^{3}$ Not significant.

standing crop of selected herbaceous species and categories of vegetation. Treatment means were compared using Fisher'sprotected least significant difference (Steel and Torrie 1980).

\section{Results and Discussion}

Precipitation was below normal at 6 of 7 sites during the studies (Fig. 1). Precipitation amounts in 1987 were $18 \%$ above the longterm average at Lincoln and $6 \%$ below average at Bloomfield. Precipitation at Lincoln in 1988 and 1989 was 31 and $9 \%$ below normal, respectively. Amount of precipitation at Virginia was 38 and $27 \%$ below normal in 1988 and 1989 , respectively. The precipitation deficit at Lincoln and Virginia in 1988 and 1989 became more pronounced as the growing season progressed.

Fertilization increased $(P<0.01)$ warm-season grass standing crop in all prairie environments evaluated (Table 2). Burning combined with fertilization increased standing crop of warm-season grasses by 50 to $127 \%$ in 5 of the 7 tallgrass prairie environments as compared to standing crop from unburned and unfertilized areas (Tables 2 and 3 ). Warm-season grass standing crop on burned and fertilized areas was greater than on burned or fertilized areas at both sites in 1987 and near Virginia in 1988 (Table 3). Moreover, there was a trend for a similar response at the Lincoln sites in 1988 and 1989. The observed increases in standing crop were in part due to the positive effect of burning or fertilization on big bluestem and indiangrass. Big bluestem and indiangrass standing crop were increased $(P \leq 0.05)$ by burning in 4 environments and by fertilization in 3 environments. These findings are consistent with studies conducted in a tallgrass prairie in Oklahoma (Graves and McMurphy 1969 ) and in the Kansas Flint Hills (Owensby and Smith 1979) where burning and fertilization increased warm-season grass yields. Knapp and Seastedt (1986) indicated that burning benefits tallgrass prairie by removing plant biomass accumulations that can be quite large and, if allowed to remain, can stifle plant productivity. Removing this biomass enhances the light environment of the emerging plant shoots and warms the soil earlier in the spring, which increases organic matter decomposition and improves nutrient availability (Knapp 1984, Seastedt 1988). Nitrogen addition increases warm-season grass yield by overcoming any limitation in the availability of this nutrient. Seastedt (1988) determined that burned tallgrass prairies are nitrogen-limited environments because much of this nutrient is immobilized by plant roots on frequently burned sites.

The site at Virginia 1989 was the only site where warm-season grass standing crop was greater on the fertilized areas than on the burned and fertilized areas (Table 3 ). This resulted from the significant $(P<0.03)$ contribution made by prairie and tall dropseed to the total warm-season grass standing crop on unburned and fertilized areas. The standing crop of the dropseeds was $1,308 \mathrm{~kg} \mathrm{ha}^{-1}$ on unburned and fertilized areas as compared to $617 \mathrm{~kg} \mathrm{ha}^{-1}$ produced on burned and fertilized areas. Difference in warm-season grass standing crop between the burned and unburned areas that were fertilized may also result from burning-induced removal of the protective mulch layer and below-average precipitation during 1988 and 1989 (Fig. 1). The combined effect of these 2 factors could have depleted the soil water available for plant growth on burned areas more rapidly than on unburned areas.

Warm-season standing crop was significantly affected $(P \leq 0.05)$ by the main effect of atrazine only at the Bloomfield site (Tables 2 and 4). The positive response of warm-season grasses to atrazine occurred in conjunction with suppression of the cool-season grass component of the plant community. This suppression may have contributed to improve warm-season grass standing crop by reducing competitiveness of the cool-season grasses. Waller and Schmidt (1983) determined that atrazine applied in the spring increased yield of warm-season grasses in an eastern Nebraska tallgrass prairie by suppressing smooth brome and Kentucky bluegrass. Growth enhancement caused by atrazine may also account for the 97\% increase in warm-season grass standing crop where the herbicide was applied at the Bloomfield site. Sublethal doses of striazines have been found to stimulate growth of perennial grasses (Reis 1976) and improve blue grama [ Bouteloua gracilis (H.B.K.) lag ex Steud.] drought tolerance (Hyder et al. 1976).

The warm-season grass component of the remaining 6 tallgrass prairie environments was largely unresponsive to atrazine application. The interaction of burning by atrazine influenced standing crop of warm-season grasses at the Lincoln and Virginia-H sites in 1988 (Tables 2 and 4). Warm-season grass standing crop from areas that were treated with atrazine was no different from that on burned areas. The lack of response of the Virginia site in 1989 to atrazine was unexpected since cool-season grasses comprised $22 \%$ of the plant community (Table 1). The lack of response may be due to the relatively high amount of smooth brome, Scribner's panicum, and Wilcox's panicum, which are less susceptible to atrazine than Kentucky bluegrass. The absolute dominance of warmseason grasses and minor occurrence $(<10 \%)$ of cool-season grasses at the sites near Lincoln and Virginia in 1988 negated the positive effect of atrazine-induced cool-season grass suppression on warm-season grass standing crop.

Cool-season grasses were not a dominant component of the tallgrass prairies studied (Table 1). This reflected the date of plant harvest, which occurred well past the time of cool-season grass peak production and the good to excellent condition of the grasslands. Despite the small amount of standing crop, response of the cool-season grasses to the various treatments could be assessed. Kentucky bluegrass and annual bromes (Bromus spp.) appeared to be more susceptible to atrazine than smooth brome. Atrazine reduced $(P \leq 0.05)$ the standing crop of Kentucky bluegrass in 4 of the 5 environments sampled in 1988 and 1989. Annual bromes were 
Table 5. Mean standing crop of forbs harvested in summer following applications of fire, fertilizer, and atrazine in the spring to grassland sites near Bloomfield, Lincoln, and Virginia, Nebraska.

\begin{tabular}{|c|c|c|c|c|c|}
\hline \multirow[b]{2}{*}{$\begin{array}{l}\text { Spring } \\
\text { burning }\end{array}$} & \multirow[b]{2}{*}{ Atrazine } & \multicolumn{2}{|c|}{1987} & \multirow{2}{*}{$\frac{1988}{\text { Virginia- }_{\text {H}^{1}}}$} & \multirow{2}{*}{$\begin{array}{l}1989 \\
\text { Lincoln }\end{array}$} \\
\hline & & $\begin{array}{l}\text { Bloom- } \\
\text { field }{ }^{1}\end{array}$ & Lincoln ${ }^{2}$ & & \\
\hline & kg a.i. ha ${ }^{-1}$ & \multicolumn{4}{|c|}{$\ldots \ldots+\mathrm{kg} \mathrm{ha}^{-1} \ldots \ldots \ldots$} \\
\hline None & 0 & 323 & $298^{\circ}$ & 149 & 391 \\
\hline None & 2.2 & 44 & 61 & 48 & 53 \\
\hline Burn & $\mathbf{0}$ & - & 756 & - & 198 \\
\hline \multirow[t]{2}{*}{ Burn } & 2.2 & - & 173 & - & 296 \\
\hline & LSD (0.05) & 271 & 258 & 48 & 258 \\
\hline
\end{tabular}

IStanding crop averaged over burning and fertilizer treatments.

2Standing crop averaged over fertilizer treatments.

common only on the Virginia-G site and were completely eliminated from the community by burning or atrazine application. In contrast, smooth brome standing crop was reduced $(P \leq 0.05)$ on only 2 of 7 sites following treatment with atrazine. Waller and Schmidt (1983) observed that smooth brome was more resistant to application of atrazine in late April than Kentucky bluegrass. The native cool-season grasses, Scribner's and Wilcox's panicum, were not adversely affected by atrazine application. Standing crop of these grasses actually increased $(P<0.01)$ from 151 to $287 \mathrm{~kg} \mathrm{ha}^{-1}$ following atrazine application at the site near Virginia in 1989. Atrazine deactivation by carbon in the ash residue remaining after burning did not appear to influence cool-season grass response to atrazine on plots that were burned. Engle et al. (1990) found that the phytotoxic activity of atrazine on prairie threeawn (Aristida oligantha Michx.), declined when the herbicide was applied within 30 days after burning a tallgrass prairie in Oklahoma. They suggested that the atrazine was adsorbed by the ash and immobilized, making it unavailable for uptake by prairie threeawn.

Forb standing crop was significantly reduced by atrazine or burning followed by atrazine application in 4 of the 7 grassland environments (Table 5). Similarly, atrazine reduced forb yields on rangeland in central Texas (Petersen et al. 1983) and tallgrass prairie in central Oklahoma (Gillen et al. 1987). The lack of forb response at the remaining 3 sites in these studies was related to composition of the forb component of the prairie communities. The dominant forbs on the site near Lincoln in 1988, lead plant (Amorpha canescens Pursh) and silver-leaf scurfpea (Psoralea argophylla Pursh), appeared to be resistant to atrazine application. Houston (1977) and Gillen et al. (1987) found that a native leguminous forb, slim-leaf scurfpea ( $P$. tenuiflora Pursh), was resistant to atrazine. Forb response to the atrazine was difficult to assess at the grazed sites near Virginia in 1988 and 1989 because so few forbs were present. Low forb occurrence resulted from annual applications of 2,4-D at rates of 1.1 to $2.2 \mathrm{~kg} \mathrm{a.i.} \mathrm{ha}{ }^{-1}$ to control musk thistle (Carduus nutans L.) for a 6-year period before this study was started.

\section{Management Implications}

Burning combined with fertilization improved productivity of the warm-season grass component of tallgrass prairie communities in good to excellent condition. The economic feasibility of using fire and fertilization to improve tallgrass prairie productivity will be determined in part by how much additional forage a producer needs to sustain livestock during the summer. Low availability of high quality forage during the summer is typically the factor that most limits livestock enterprises in the eastern Central Great Plains since cool-season forage and crop residues for fall, spring, and winter grazing are plentiful. Alleviating this forage shortage should benefit producers in this region. Additional research is needed to determine if delaying burning to later in May would reduce soil water loss early in the growing season and further improve warmseason grass yields. Atrazine applied in the spring was generally ineffective in improving warm-season grass standing crop and adversely affected forbs in the grassland communities studied. The primary utility of atrazine application appears to be as a practice to renovate degraded prairie communities dominated by introduced cool-season grasses (Samson and Moser 1982) and not to improve the productity of tallgrass prairies in good to excellent condition.

\section{Literature Cited}

Anderson, V.L., and R.A. McLean. 1974. Design of experiments: A realistic approach. Marcel Dekker, Inc. N.Y.

Engle, D.M., T.G. Bidwell, J.F. Stritzke, and D. Rollins. 1990. Atrazine and burning in tallgrass prairie infested with prairie threeawn. J. Range Manage. 43:424-427.

Gillen, R.L., D. Rollins, and J.F. Stritzke. 1987. Atrazine, spring burning, and nitrogen for improvement of tallgrass prairie. J. Range Manage. 40:444-447.

Graves, J.E., and W.E. McMurphy. 1969. Burning and fertilization for range improvement in central Oklahoma. J. Range Manage. 22:165-168.

Houston, W.R. 1977. Species susceptibility to atrazine herbicide on shortgrass range. J. Range Manage. 30:50-52.

Hyder, D.N., W.R. Houston, and J.B. Burwell. 1976. Drought resistance of blue grama as affected by atrazine. J. Range Manage. 29:214-216.

Knapp, A.K. 1984. Post-burn differences in solar radiation, leaf temperature and water stress influencing production in a lowland prairie. Amer. J. Bot. 71:220-227.

Knapp, A.K., and T.R. Seastedt. 1986. Detritus accumulation limits productivity of tallgrass prairie. BioScience 36:662-668.

Owensby, C.E., and E.F. Smith. 1979. Fertilizing and burning Flint Hills bluestem. J. Range Manage. 32:254-258.

Petersen, J.L., R.L. Potter, and D.N. Ueckert. 1983. Evaluation of herbicides for manipulating herbaceous rangeland vegetation. Weed Sci. 31:735-739.

Rehm, G.W. 1984. Yield and quality of a warm-season grass mixture treated with N, P, and atrazine. Agron. J. 76:731-733.

Reis, S.K. 1976. Subtoxic effects on plants. p. 313-340. In: Audus, L.J. (ed.) Herbicides: Physiology, biochemistry, ecology, Academic Press. London.

Samson, J.F., and L.E. Moser. 1982. Sod-seeding perennial grasses into eastern Nebraska pastures. Agron. J. 74:1055-1060.

Seastedt, T.R. 1988. Mass, nitrogen, and phosphorus dynamics of foliage and root detritus of tallgrass prairie. Ecology 69:59-65.

Steel, R.G.D., and J.H. Torrie. 1980. Principles and procedures of statistics. McGraw-Hill Book Co. N.Y.

Towne, G., and C.E. Owensby. 1984. Long-term effects of annual burning at different dates in ungrazed Kansas tallgrass prairie. J. Range Manage. 37:392-397.

Waller, S.S., and D.K. Schmidt. 1983. Improvement of eastern Nebraska tallgrass range using atrazine and glyphosate. J. Range Manage. $36: 87-90$. 